(This is a version of an article with the same title published in Continuum: Journal of Media and Cultural Studies, vol 23, no 5, 2009, pp. 575-595.)

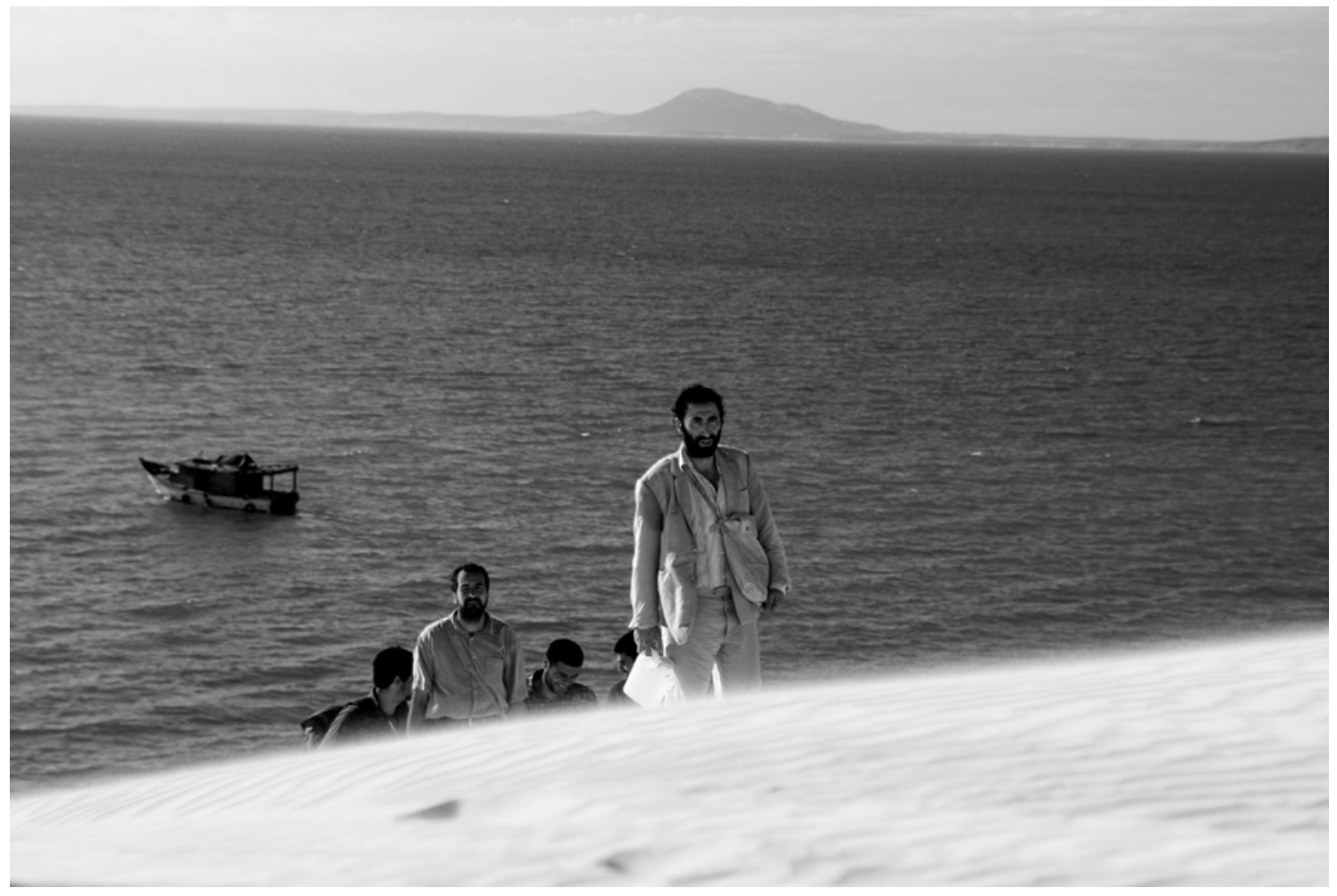

Still from Lucky Miles @ Sam Oster / Silvertrace, 2007. Reprinted with permission.

\title{
Introduction:
}

\section{Heterochronotopes of Exception and the Frontiers and Faultlines of Citizenship}

\section{Suvendrini Perera and Jon Stratton}

Department of Cultural Studies, Curtin University of Technology, Perth, Western Australia.

GPO Box U1987 Perth, Western Australia 6845.

Anyone who had imagined that the demise of the Howard government would put an end to the public preoccupation with boat arrivals that characterised its period in office was proven wrong in early 2009 when the arrival of unauthorised asylum seekers once again become a topic of national prominence. In 2008 fourteen boats carrying people seeking 
asylum had reached Australian waters. While this figure was a significant increase from the three boats detected the previous year, it remained relatively unremarked until April 17, 2009, when a boat, identified as Suspected Illegal Entry Vessel (SIEV) 36, carrying 47 Afghan asylum seekers, exploded as it was being towed to Christmas Island where those on board would be detained while their asylum claims were assessed.

The event conjures memories of the unnamed SIEV, SIEV X, which, sank in international waters off Java on October 19, 2001, causing the deaths of 353 people, primarily women and children (Marr and Wilkinson 2003; Kevin 2004). Unlike that desperate night, this time the Australian navy was on hand to help. Still, five people died. Many more were severely burned and had to be air-lifted to hospitals in Darwin, Perth and Brisbane. While some of us remembered SIEV X, for others the explosion provided an opportunity to return to the associations of violence and terrorism with asylum seekers stirred up by the Tampa and 'children overboard' affairs at the height of the borderpanic of 2001. ${ }^{1}$ The West Australian Premier, for one, was quick to jump to the conclusion that the asylum seekers had deliberately set fire to their own boat (Hayward 2009; Farr and Rehn 2009). In the ensuing days the notion of ‘queue jumping' was implicitly and explicitly canvassed through questions about whether the wounded and traumatised were consuming scarce hospital space and medical resources, thereby depriving 'ordinary Australians' (Rondganger, 2009).

Up to that moment, six boats had been intercepted in Australian waters during 2009 with 264 asylum seekers and 12 crew aboard. A few days later, the discovery of a boat carrying asylum seekers who had sailed all the way from Sri Lanka provided copy for a renewal of old scares of invasion by sea and Australia's seeming vulnerability as an 
island of stability in an 'arc of insecurity' stretching from the Indian Ocean to the Pacific (see Perera 2009 forthcoming). As world news headlines focused on the bitter end of the long war in Lanka local fears proliferated and 'experts' were called on to predict dire consequences for Australia in the form of floods of refugees. The discovery of another group of asylum seekers who had apparently survived undiscovered for several days on Melville Island added to an escalation of the reporting about asylum seekers and to demands for increased maritime surveillance and patrolling of the borders.

It is in this context that the five interlinked essays in this issue of Continuum consider questions of the (re)production of borders—biopolitical, spatial, legal, historical, symbolic—intended to contain and exclude asylum seekers. The essays situate these modalities and technologies of exclusion in the context of broader questions of nationalism, citizenship, biopolitics, neoliberalism and the transnational genealogies of colonialism and racism. They make the collective argument that the issue of border security is not the preoccupation of a single political party or government, but serves to magnetise a cluster of concerns and issues that are central to contemporary formations of citizenship, identity, territoriality and statehood in the west.

The term 'heterochronotope' in the title is taken from Joseph Pugliese's essay in this volume. It signifies a seriality of temporally and spatially discontinuous and yet connected sites that 'bring into focus the fraught and contradictory relations between bodies and borders'. The essays collected here consider the relations between bodies and borders in the context of biopolitical regimes (Palombo); citizenscapes and national narratives (Perera), the boundaries of sexual and gendered behaviour and the biologicalcultural reproduction of the nation (Phillips), geopolitical and raciological faultlines 
(Pugliese) and politico-economic formations of neoliberalism (Stratton). The contributors are a mix of early career and more established researchers who have worked together in various ways over several years. The connections and differences between their essays indicate the distinctive theoretical, political and geographic focus of each, and the diverse interdisciplinarities they engage with (literary and historical studies, feminism, political economy, diaspora studies) within the broader discipline of cultural studies.

\section{Neoliberal Citizenship and the Topologies of Exclusion}

The Howard government's policies towards asylum seekers are usually discussed in the context of an increase in asylum seeker arrivals through the late 1990s and early 2000s. In 1997/8 157 people arrived on 13 boats. This figure increased to 926 people in 1998/9 and, in 2001/2, six boats carried 1,212 people to Australia. From this high, numbers of arrivals decreased with 56 arriving in 2005/6, 135 in 2006/7 and 25 in 2007/8. Then, when the numbers started increasing again in 2009, the response of both the media and the Liberal Opposition was to lay the blame on a perceived 'softening' on refugee policy. On May 6, 2009, under the headline, ‘Kevin Rudd faces biggest boatpeople spike since Pacific Solution', Paul Maley and Paige Taylor wrote in The Australian of 'the 18th boat to be detained since the Rudd Government announced a softening of detention policies last September'. While the article acknowledges the government's claims that 'favourable conditions at sea, an abundance of boats and the brimming global pool of refugees displaced by violence in the Middle East [are] reasons for the surge', it nevertheless dates the increase to the Labor government's shift in policy towards asylum seekers and glosses Malcolm Turnbull, the present leader of the Liberal and National 
coalition, as saying that 'yesterday's arrival made it clear Labor's border protection policies had failed' (Maley and Taylor 2009).

In this way the recent increase in asylum seekers arriving by boat has been tied to local Australian anxieties about border security and protection from unwanted migrants. Yet this focus on domestic policy and minor fluctuations in numbers is a distraction. Border security is not simply a local matter. While concerns over the security of the border are as old as the nation-state, the term has gained a new valence since the attacks on the Pentagon and on the Twin Towers of the World Trade Center on September 11, 2001. Suddenly, the United States and its allies found a new threat to the integrity of their territories. In Australia, the coalition under Howard won a federal election in November two months after Australians stayed up watching the shocking television images of the destruction of the Twin Towers. In August, Howard's incumbent government, behind in the polls, had already moved to make asylum seekers arriving by boat a wedge issue for the forthcoming election by refusing to allow the Norwegian container ship MV Tampa, which had picked up 438 mainly Afghans from a sinking boat, and attempted to land them on Christmas Island. The Tampa event became the trigger for the establishment of the Pacific Solution. At the time that the Tampa was being refused landing permission, the government attempted to pass the Border Protection Bill 2001. This would have allowed the government to direct any ship in any circumstance out of Australian waters, and the use of any reasonable force to ensure that this happened. The Bill also established that there could be no recourse to the courts for any person affected by such action. In this way the Bill overrode all existing Australian law. The intention was to make the Bill retrospective to legalise the actions taken against the Tampa. The Bill was defeated in the 
Senate. However, on September 18, a week after the attacks in the United States, a revised Bill was passed. It was also in September that the Migration Amendment Act was passed, excising Christmas Island along with many other offshore islands from the Australian migration zone- the area within which asylum seekers could claim refugee status (Marr and Wilkinson 2002).

The Border Protection Bill, the Migration Amendment Bill and the establishment of the Pacific Solution made the Australian border visible in new ways and in doing so had a transformative effect on how it is experienced and perceived (Perera 2002a). The backdrop to these developments was the attacks on the US World Trade Centre and the Pentagon. These attacks, then, provided a pretext and a context for the new securitisation of the Australian border. However, we need to remember that the primary concern of this legislation was not the deterrence of terrorism but the exclusion of asylum seekers who arrived by sea. This combination of events, a watershed in the experience of the Australian border, is an aspect of the territorial expression of Australia as a neoliberal state. Matthew Sparke has written about 'neoliberalism and its reterritorialization of social and political life' (2006). In an article about the Nexus program, a system set up to facilitate movement between Canada and the United States, specifically along the Vancouver Seattle corridor, he writes that although the emergence and significance of the Nexus program is 'a context-contingent response to the contradictory imperatives of national securitization and economic facilitation . . . the program exemplifies broader changes to citizenship--most notably, new transnational mobility rights for some and new exclusions for others--under a combination of macroscale neoliberal governance and microscale neoliberal governmentality’(2006). Here, Sparke sets up well the general 
connections between the border and citizenship, between securitisation and mobility, which are effects of neoliberalisation.

David Harvey explains that: 'Neoliberalism is in the first instance a theory of political economic practices that proposes that human well-being can best be advanced by liberating entrepreneurial freedoms and skills within an institutional framework characterised by strong property rights, free markets, and free trade’ (2005, 2). Its foundation is a privileging of the market over all other concerns, including moral ones, and an emphasis on individual entitlements and responsibilities over older notions of the public or collective. As Wendy Brown elaborates, 'neoliberal rationality while foregrounding the market, is not only, or even primarily, focused on the economy; it involves extending and disseminating market values to all institutions and social actions’ (Brown 2005, 30-40).

Neoliberalisation has brought about a fundamental redefinition of the institution of citizenship along marketised and seemingly 'non-ideological' lines_although, as the essays here suggest, culture and race still stage a covert return through notions of ‘cohesion’ and ‘values’ (Perera, 2007). The traditional nation-state was represented as fundamentally inclusive for those defined as citizens. In conventional western political theory, citizenship has also been closely associated with democracy. For example, Richard Bellamy writes that, 'at its best, democratic citizenship ... promote[s] a degree of equity and reciprocity among citizens' $(2008,8)$. In this understanding, the borders of the nation-state were thought to function to delimit those included from those excluded, where inclusion meant the right to certain entitlements guaranteed by membership of the state. However, we need to remember that this liberal conceptualisation of citizenship 
masks its exclusionary organisation, found most obviously in the treatment of those neither male nor white. Critiquing the neoliberal primacy of the contract-based marketisation of social relations from this traditional perspective, Margret Somers argues that: 'Contractualizing citizenship distorts the meaning of citizenship from that of a shared fate among equals to that of conditional privilege' $(2008,3)$. With the setting aside of assumptions about a shared social contract, and indeed of the idea of society itself, the neoliberal state reveals a grounding founded on an idea of graded exclusion and, as Stratton has argued elsewhere: 'It is in this context, and in the ordering of the neoliberal state's hierarchisation founded on the violence inflicted on those relatively excluded, that we find the neoliberal state's preference for authoritarian government' (2009, 21).

While there remain, as a number of the essays here argue, deep continuities between imperial histories and the faultlines of contemporary globalisation, neoliberal policies have had the effect of transforming understandings of citizenship in many (if not all) western societies, including in Australia. Rights of citizenship are graded according to what the state calculates as an individual's (or a group's) potential to contribute to the marketised order. The consequence, as Somers, writing about the United States, puts it, is that there is 'an evergrowing superfluous population, no longer accommodated by a regime in which market value is the chief criterion for membership' $(2008,5)$.

This is one context for understanding the Howard government's introduction in 1999 of Temporary Protection Visas (TPVs) instead of permanent residence rights, for those asylum seekers assessed to be refugees. TPVs allowed the holder to stay in Australia for three years after which time their status was reassessed. In the meantime holders were only eligible for limited social services and had no family reunion rights. 
The TPV system was held responsible by many analysts for the disaster of SIEV X as the wives and children of men who had temporary rights to be in Australia but were unable to be legally joined by their families were forced to put themselves at risk by undertaking a covert voyage in dangerous conditions (Fekete 2008, 100-1; Perera 2008, 76-9).

‘Temporary Protection’ as a technology that places the asylum seeker in a state of suspension between legal and illegal, physical incarceration and legislative exclusion, is an extension of neoliberalism’s practices of 'graded exclusion’ discussed above. Such practices exceptionalise specific groups by either subjecting them to, or suspending them from, special laws within the territorial limits of the nation, establishing new legal forms of distinguishing between citizens and others, and producing modalities of differentiation and stratification as well as new biopolitical topologies within the citizenscape (see Palombo this volume). The intervention into Aboriginal communities in the Northern Territory, enabled by a suspension of the Racial Discrimination Act, is one instance of this practice as it applies to Indigenous groups (see Watson 2008).

Such reconfigurations and stratifications of citizenships need to be consistently situated in global contexts and within what Pugliese terms the 'transnational infrastructure of biopolitical and colonial regimes [that] ensure ... the reproduction, across different sites and bodies, of violent relations of power' (Pugliese, this issue). Walden Bello writes that:

The process of neoliberal reform ... was marked by destabilising contradictions, in the North and in the South. Liberating capital from the constraints of governments that had imposed a compromise between labor and capital and a modus vivendi between northern capital and developing elites entailed (1) bringing down wages, which meant cutting the engine of demand that capital needed in order to reproduce itself profitably, and (2) adding to the ranks of the global unemployed, as the penetration of goods and capital into less developed economies bankrupted local firms and farms, eliminating millions from the market (Bello, 2005, p 83). 
The total number of refugees as a product of such forces is staggering. The UNHCR estimated that 'there were 11.4 million refugees outside their countries and 26 million others displaced internally by conflict or persecution at the end of 2007' (UNHCR 2008). Globalisation, and the spread of neoliberal economic policies, has gone hand in hand with increased migration. In a working paper for UNHCR, Susan Martin writes that, in 1965, the United Nations Population Division estimated that 76 million people fitted the description of long-term international migrants. As of 2000, Martin estimates that the figure had risen to 150 million. Martin notes that, since the 1980s, this increase is set against a slowing in the growth of the total global population. She also notes that: 'The most rapid growth in the number of international migrants tends to occur as a result of refugee crises’ (Martin 2001). These crises are often caused by war and discrimination that are themselves directly or indirectly the products of the globalised, neoliberal policies described by Bello.

What Sparke describes as the contradictory imperatives of national securitisation and economic facilitation of border movement, then, are two sides of the same coin — the protection of the state from unwanted migrants, those who it is considered will not contribute to the marketised order founded on a series of racialised and gendered discriminations, and the encouragement of those migrants who it is considered will so contribute. This is the background for the changes in treatment of asylum seekers in Australia over the period since the election of the Hawke Labor government in 1983. Hawke's was the first Australian government to start implementing neoliberal policies and, after Paul Keating took over the prime ministership, the government introduced mandatory detention for asylum seekers arriving by boat in 1992 . 
This trajectory has not been deflected by the minor changes adopted by the Rudd government. The Australian state remains bound up in the web of neoliberal effects that now span the world. While it is true that the Rudd Labor government, when it took office in 2007, ended the policy of the mandatory detention of children and produced a 'statement of values' on the humane treatment of asylum seekers, critical aspects of the Howard regime’s program for forestalling refugee claims remain in place (see Palombo, this issue). The Howard government's key technologies for deterring refugee claims by people who arrived by boat were mandatory indefinite detention, the introduction of Temporary Protection Visas, the establishment of off-shore detention camps on Nauru and Papua New Guinea (the 'Pacific Solution') and the excision of offshore islands from the migration zone. Despite the abolition of the Pacific Solution by the Rudd regime, the fact that asylum seekers continue to be taken to Christmas Island-a space that remains excised from the migration zone-indicates that Australia continues to use exception as a technology for dealing with asylum seekers (for further discussion of Australian asylum seeker policy in the context of Giorgio Agamben’s concept of exception see Perera 2002b). In this sense Howard's avowal that the Tampa refuges would not be allowed to set foot on Australian soil, the rationale for the 'Pacific Solution', continues to hold.

At the same time, as this issue goes to press, a spate of racist attacks_-beatings, stabbings, muggings, arson attacks—against international students at Australian universities has at last begun to attract national attention after initial denials by Australian authorities (police, state and commonwealth politicians) that the attacks had a racial motivation (see, for example Callaghan 2009). Although this attention has been the consequence of a series of increasingly public interventions by the Indian government, 
Indian students are by no means the sole targets of the violence. In separate incidents in Sydney and Perth international students from China have been raped and murdered. In Sydney in 2008 Wei Liao was raped, along with her Korean boyfriend, and then fell to her death from her third-floor apartment trying to escape her attacker (Lawrence 2008; Lawrence and Williams 2008). In Perth, Jiao Dan was horrifically raped and murdered after getting off a train on her way home (Jones 2009).

The attacks on Indian and Chinese international students have been differently focused. They function in the terms of the everyday racism (Stratton 1999) that pervades Australian society. The attacks on male Indian students suggest a link to the British colonialist feminisation of Indian men (see for example, Westwood 2002 65). Such an imagining could encourage a racialised violence bent on putting these apparently well-off young men in their place in the Australian racial hierarchy. The sexual attacks on female Chinese students suggest the ongoing orientalisation of the Chinese woman. In her book, The Chinese Exotic, Olivia Khoo writing about 'popular notions of exoticism in relation to Asian femininity generally and Chinese femininity in particular' $(2007,5)$ argues that: 'The interest in Asian femininity, when traced to its exoticist origins, is usually motivated by, and marketed as, a (hetero)sexual encounter, whereby any difference becomes a violent, yet sublime, part of that encounter' $(2007,6)$. These colonialist constructions of Indian men and Chinese women influence the motivation of the crimes against the members of each group, as do the anxieties and rage produced by the breakdown of these very stereotypes.

In the shows of force by students from India on the streets of Melbourne and Sydney, as in the flexing of muscle by the Indian government, we see the emergence of 
challenges to old hierarchies. The raised fists, leather jackets and shaved heads of the students stage a kind of aggressive masculinity that belies the subservient and feminised orientals of Raj fantasies. In turn these displays set off competing assertions by other groups jostling for position within the complex hierarchies of ethnicity, religion and race in Australia—for example the competing local machismos of 'Indians' and 'Lebanese' in the Sydney suburb of Harris Park.

Among other things, the outbreaks of racist violence against international students on a national scale suggests that the careful differentiation between productive and unproductive 'others' — between the official welcome extended towards international students who are seen as beneficial to the neoliberal economy and the punitive policies directed at refugees who are seen as liabilities (Stratton ???[ref to come] )—or between 'flexible' forms of mobility as against permanent migration, are unable to be sustained within national and geopolitical contexts that continue to be premised on racist imaginaries and on a system of globalised inequality. The 'foreign student' and 'the refugee' in this sense are two aspects of the same figure, and represent the body of 'moving people' (Soguk 2007) produced by the same globalised forces that enable the (circumscribed and provisional) 'mobility' of one while attempting to contain, blockade and violently terminate the other's aspirations to a similar mobility.

\section{In/visible Bodies and Economies of Simultaneity}

In two very important essays, 'Beyond the Straits' and 'Cast Away’ Peter Hulme contemplates a photograph taken on a beach at Zahara de los Atunes in Spain in 2000 by the Spanish photographer, Javier Bauluz. It depicts a couple sunning themselves on a 
beach apparently indifferent to, and unaffected by, the fact that the drowned body of an asylum seeker is lying only a few feet away. The photograph, as Hulme proceeds meticulously to explicate, 'casts its shadow back to the sixteenth century' $(2005,44)$ and to southern Spain as a historic frontier between Europe and its others. This 'historical shadow', Hulme shows, is also the source of the emergence of a new figure, the castaway, as an artifact of colonial expansion (2004). Hulme's insights are central to two of the contributions to this volume, Pugliese’s 'Crisis Heterotopias and Border Zones of the Dead' and Perera's 'White Shores of Longing'. In 'Crisis Heterotopias’ Pugliese contemplates a very similar photograph to the one referred to by Hulme, this time set on a beach in Torregaveta, southern Italy, where unconcerned beachgoers step over the dead bodies of two Roma girls. Pugliese's essay proceeds to locate the photograph in the contexts of national histories of racialised exclusion and the faultlines of regional geopolitics.

The border, Nevzat Soguk writes evocatively, 'laces the refugee's shoes and makes him invisible'. Its 'primary raison d'être' is its 'momentary relationship with the refugee' (Soguk 2007, 284). In light of the beach images discussed by Hulme and Pugliese, the 'invisibility' that the border confers on the asylum seeker or refugee is revealed as double-edged. Borders within and at the frontiers of states invisibilise the refugee, dehumanising her into 'the illegal', even as these borders sometimes facilitate her movements because of this very invisibility. The border, then, instigates, incites and entangles the refugee; now catching her in its searchlights, now enabling her to secret herself in its folds and crevices that sometimes protect and at other times kill (Pugliese 2009). The border sets the refugee in motion and trips her up. Drawing on Michel 
Foucault, Pugliese theorises this doubleness of borders through the logic of simultaneity: 'we are in the epoch of juxtaposition, the epoch of the near and the far, of the side-byside, of the dispersed'.

The logic of simultaneity enables mobility and blockage, visibility and invisibility, flexibility and entrapment. It makes intelligible the doubleness of places (the resort/prison island), mobilities (the cast away/the refugee) and bodies (their gendered and sexed attributes and limits), as it determines biopolitical differentiations and discriminations. Kristen Phillips' essay in this issue focuses on border politics and the biopolitical life of the nation in the context of gender and sexual behaviour. In her 'Provocative Women in the Borderzone' Phillips argues that the sense that 'there is an Australian national crisis' over the arrival of refugees and their presence within the community engenders anxieties 'to do with the reproduction of the nation, the life of the nation'. Considering three recent texts, an ABC miniseries Marking Time (2003), Randa Abdel-Fatteh's teen novel Does My Head Look Big In This? (2005), and Tom Zubrycki’s documentary film Molly and Mobarak (2003), Phillips explores how these stories might 'provide a useful starting point for considering the idea that in Australian national culture, against the backdrop of anxious border politics, the possibility that women are not contained or complicit is felt as a moment of national crisis, as one aspect of the crisis about the life of the nation which might be used to justify the suspension of the civil order'.

The 'suspension of the civil order' is also the concern of Lara Palombo's genealogical account of the camp as a biopolitical technology of power that is foundational to the formation and reproduction of white sovereignty in Australia. She 
traces the institutionalisation of this sovereignty through different moments and in relation to different lives_-Indigenous peoples, indentured workers, 'Enemy Aliens' in World War Two, women, refugees, asylum seekers and migrants. Both Palombo and Phillips consider the possibilities of the extension of the state of exception outside the spatial arrangement of the camp: Phillips argues that that the 'sense of national crisis or state of exception is also significantly connected to certain assumptions about reproduction and women as reproductive bodies' while Palombo concludes her discussion of different spatial formations of the camp by considering its ramifications for welfare and social security policies that produce new borders within the nation.

Whereas Palombo is concerned with tracing the continuities between historical mutations of the camp in Australian history, Pugliese's essay marks the serial nature of penal camps in relation to Italian national histories by focusing on the hidden past of the island of Lampedusa as one of a number of internal penal colonies in post-unification Italy. Here insurgents from the south, racialised and criminalised as African, were held in brutal conditions—conditions that not coincidentally stage their violent return in the present through Lampedusa's role as a place of incarceration for refugees from Africa. Lampedusa as an island situated on a cultural faultline between Europe and Africa, Pugliese goes on to show, finds its structural parallel in Christmas Island, another holding place for asylum seekers on the faultline between Australia and Asia.

The 'transnational dimensions of carceral archipelagos' that Pugliese makes visible in his essay are simultaneously marked by the violent disjunctions that inscribe these spaces as both resorts and prisons, as luxury getaways for some and high security holding places for others. Perera's essay pursues a similar disjunction through the 
asymmetries that mark the literary trope of the 'castaway' as exemplified in individualised heroes such as Robinson Crusoe and the 'collective stories of empire's historical and present-day refugees, of whole peoples cast away in the name of progress, casually removed from their homelands to lives in the brutal enclosure of a camp or exiled to foreign shores’. Beginning with the true story of some asylum seekers from Sri Lanka cast ashore at Coral Bay in Western Australia in 2001, Perera tracks the ways in which their story is re-presented in two very different cultural texts, the film Lucky Miles (2007) and a community production, Theatre of Migration (2001). These representations of the refugee at the threshold of citizenship, as an 'impossible subject' of the nation, Perera argues, illuminate the nature of citizenship for those 'within'.

Jon Stratton’s essay, 'Welcome to Paradise’ also focuses on Lucky Miles to anchor a series of concerns about Australian nationalism, neoliberalism and the border. Stratton is particularly interested in the relationship between the remembered past of the film’s present (1990) and the year in which the film was first viewed (2007). Nostalgia for a seemingly kinder and gentler time when policies towards asylum seekers were less harsh, he suggests, works to obscure the continuities between then and now. The essay pursues the relationship between neoliberal policies and the anxieties generated by the border, arguing that the fear of the disordered and chaotic presence of asylum seekers generated since the 1990s 'is a consequence of the establishment of a new partially permeable border, a border with minimal import tariffs and through which flows of desired entrants are encouraged while those not desired are to be kept out at all costs'. In a recent discussion of the implications of the introduction of 457 (temporary work) visas Peter Mares writes that most Australians: 
largely behave as if we lived in the twentieth century, when migrants came by sea and stayed for good. We endure periodic panics when boats carrying asylum seekers [come] to our shores from Indonesia and we agonise about racism when Indian students are beaten up on their way home from work. But a serious debate about the fundamental shift from permanent to temporary migration and what it might mean for our collective sense of identity and social cohesion is yet to begin (Mares 2009).

What Stratton’s essay points to, and what we have attempted to argue in this introduction, is that Mares’s 'before’ and 'after' schema needs complicating. Rather, the exceptionalisation of sections of the population, either in temporal or spatial terms, has always been a characteristic of the heterochronotopes of the Australian border and of the territorial and statist order of which it is a part.

For financial assistance for this project we are grateful to the Centre for Advanced Studies in Australia, Asia and the Pacific (CASAAP) at Curtin University of Technology. This issue could not have been put together without the research and editorial skills of Susan Leong, and we thank her for her clam, efficiency and eye for detail. Warm thanks also to Panizza Allmark, Vijay Devadas and Tanja Dreher for their ready assistance with various aspects of this issue.

The term borderpanic is borrowed from the Borderpanic Symposium in held at the Museum of Contemporary Art in Sydney in September 2002. Two of the contributors to this volume were participants.

\section{REFERENCES}

Bellamy, Richard. 2008. Citizenship: a Very Short Introduction. Oxford: Oxford University Press.

Bello, Walden. 2005. Dilemmas of Domination: the Unmaking of the American Empire. New York: Metropolitan Books.

Brown, Wendy. 2005. Edgework: Critical Essays on Knowledge and Politics. Princeton: Princeton University Press.

Callaghan, Greg. 2009. India tells students not to hit back over violence. Australian. http://www.theaustralian.news.com.au/story/0,25197,25613434-12332,00.html.

Farr, Malcolm and Alison Rehn. 2009. Asylum seeker boat explosion fans border row. Daily Telegraph, April 17 .

Fekete, Liz. 2008. Xeno-racism and the Demonisation of Refugees: A Gendered Perspective. In Women, Crime and Social Harm: Towards a Criminology for the Global Era, ed. Maureen Caine and Adrian Howe, 95-106. Oxford: Hart.

Harvey, David. 2005. A Brief History of Neoliberalism. Oxford: Oxford University Press.

Hayward, Andrea. 2009. Barnett under fire over sabotage claims. WA Today, April 17. 
Hulme, Peter. 2004. Cast Away. In Sea Changes: Historicizing the Ocean, ed. B. Klein and G. Mackenthun, 187-97. London: Routledge.

—. 2005. Beyond the Straits: Postcolonial Allegories of the Globe. In Postcolonial Studies and Beyond, ed. A. Loomba, S. Kaul, M. Bunzl, A. Burton, and J. Esty, 41-61. Durham: Duke University Press.

Jones, Christiana. 2009. Man guilty of murdering, raping Chinese student. West Australian. http://www.thewest.com.au/default.aspx?MenuID=77\&ContentID=134854.

Kevin, Tony. 2004. A Certain Maritime Incident: the Sinking of SIEV X. Melbourne: Scribe.

Khoo, Olivia. 2007. The Chinese Exotic: Modern Diasporic Femininity. Hong Kong: Hong Kong University Press.

Lawrence, Kara. 2008. Court hears allegations of rape and murder. Daily Telegraph. http://www.news.com.au/dailytelegraph/story/0,24576116-5001021,00.html .

Lawrence, Kara, and Williams, Lauren. 2008. Tragic International Rape/Murder Case. China Daily. http://bbs.chinadaily.com.cn/viewthread.php?gid=2\&tid=619340.

Maley, Paul and Paige Taylor. 2009. Kevin Rudd faces biggest boatpeople spike since Pacific Solution. The Australian, May 16. http://www.theaustralian.news.com.au/story/0,,25436120-2702,00.html.

Mares, Peter. 2009. The Permanent Shift to Temporary Migration. Australian Policy OnLine, June 16. http://inside.org.au/the-permanent-shift-to-temporary-migration/

Marr, David and Marion Wilkinson. 2003. Dark Victory. Crows Nest: Allen \& Unwin.

Martin, Susan. 2001. Global Migration Trends and Asylum. The Journal of Humanitarian Assistance. New Issues in Refugee Research, Working Paper No. 41. http://www.jha.ac/articles/u041.htm.

Perera, Suvendrini. 2002a. A Line in the Sea: the Tampa, Boat Stories and the Border. Cultural Studies Review, 8, no. 1: 11-27.

— 2002b. What is a Camp...? Borderlands, 1, no.1. http://www.borderlands.net.au/vol1no1_2002/perera_camp.html

—. 2007. Aussie Luck’: The Borderpolitics of Citizenship Post-Cronulla Beach', Australian Critical Race and Whiteness Studies 3.1 (2007).

-.Perera, Suvendrini. 2008. The Gender of Borderpanic: Women in Circuits of Security, State, Globalisation and New (and Old) Empire. In Women, Crime and Social Harm: Towards a Criminology for the Global Era, ed. Maureen Caine and Adrian Howe, 69-93. Oxford: Hart.

—. 2009 forthcoming. Australia and the Insular Imagination: Beaches, Borders, Boats, and Bodies. New York: Palgrave Macmillan.

Pugliese, Joseph. 2009. Civil Modalities of Refugee Trauma, Death and Necrological Transport. Social Identities, 15, no. 1: 149-165.

Rondganger, Lee. 2009. Burns victims could be discharged this week. West Australian, 20 April.

Soguk, Nevzat. 2007. Border’s Capture: Insurrectional Politics, Border-Crossing Humans, and the New Political. In Borderscapes: Hidden Geographies and Politics at Territory's Edge, ed. Prem Kumar Rajaram and Carl Grundy-Warr, 283-308. Minneapolis: Minnesota University Press. 
Sparke, Mathew. 2006. A Neoliberal Nexus: Economy, Security and the Biopolitics of Citizenship on the Border. http://faculty.washington.edu/sparke/NN.pdf .

Somers, Margaret. 2008. Genealogies of Citizenship: Markets, Statelessness and the Right to Have Rights. Cambridge, UK: Cambridge University Press

Stratton, Jon. 1998. Race Daze: Australia in Identity Crisis. NSW: Pluto.

-. 2006. Two Rescues, One History: Everyday Racism in Australia. Social Identities: Journal for the Study of Race, Nation and Culture, 12, no. 6: 657-681

- . 2009. The Murderous State: The Naturalisation of Violence and Exclusion in the Films of Neo-Liberal Australia. Cultural Studies Review, 15, no. 1: 11-32.

- . 2009. forthcoming. Uncertain Lives: Migration, the Border and Neoliberalism in Australia. Social Identities Journal for the Study of Race, Nation and Culture, 15, no. 5.

UNHCR Press Release. 2008. Global Refugee, Internally Displaced Figures Climb for Second Straight Year. June 17. http://www.unhcr.or.jp/news/press/pdf/pr080617_StatsWRD_E.pdf.

Watson, Nicole. 2009. The New Protection: Women and Contemporary Australian State. In Beyond the Hijab Debates: New Conversations on Gender, Race and Religion, ed. T. Dreher and C. Ho, 105-117. Newcastle upon Tyne: Cambridge Scholars Publishing.

Westwood, Sallie. 2002. Power and the Social. London: Routledge. 